\title{
Meskwaki Remember Action Anthropology
}

\author{
JUDITH M. DAUBENMIER
}

WHEN MEMBERS of the Meskwaki community near Tama, Iowa, gathered for their eighty-eighth annual powwow in August 2003, souvenir hunters could choose from tee shirts with Indian themes, compact disk recordings of Indian drumming and singing, or silver and turquoise jewelry. Those in search of handmade rather than mass-produced items might have found one tent's offerings particularly attractive. Across the road from the kettle-corn stand and the snow-cone tent, a vendor offered Meskwaki-made baskets from the 1940s, a magnificent hickory bow carved by an anonymous Meskwaki hunter, and a few ceramic tiles with brightly colored images in sharp relief against white backgrounds.

One of the tiles bore the image of a little Indian girl in a turquoise dress. Another featured a hunter spearing a buffalo. A third design showed a Meskwaki pipe dancer, decked out in traditional dress from the top of his roach headpiece down to his feather bustle, leggings, and bell-trimmed moccasins. Stamped on the cork backing in faded lettering was the message, "Tile Produced by Hand, Mesquakie Indian Settlement." The stand's proprietor vouched for the authenticity of the tiles, saying, "They made these here in the 50's and 60's." He was too young to remember exactly who "they" were and why members of his tribe would have adopted the art of ceramic tile production, a technique without roots in Meskwaki tradition. Aware of the tiles' links to his settlement, however, he and his wife scouted Tama-area garage sales and the Internet for them.

THE ANNALS OF IOWA 61 (Fall 2003). (C) The State Historical Society of Iowa, 2003. 

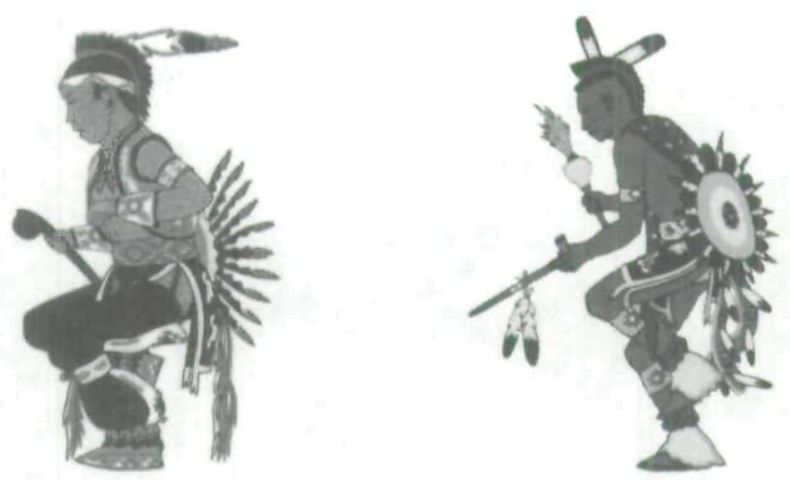

Two designs by Meskwaki artist Charles Pushetonequa for tiles produced and sold by members of the Meskwaki cooperative Tamacraft in the 1950s. (The bright colors of the originals cannot be reproduced here.)

Tribal elders who noticed the tiles might have had a variety of reactions - from vague recognition to fondness, regret, or bitterness. So it is with the elders' reactions to the enterprise that created the tiles, Tamacraft. Furthermore, Tamacraft and its tiles are part of the legacy of a larger project at the Meskwaki Settlement that stirred similarly mixed reactions.

That larger project had its roots in efforts by the University of Chicago Anthropology Department beginning in the summer of 1948 to provide fieldwork training for its graduate students. Led by University of Chicago anthropology professor Sol Tax, the fieldwork training school quickly blossomed into a new way of doing anthropology, called "action anthropology." As articulated by Tax, action anthropology called on its practitioners not only to study people, but also to make a commitment to helping the people among whom the anthropologists lived and from whose expertise they benefited. ${ }^{1}$

1. Tax briefly outlined the substance of action anthropology in several speeches and articles. One of the most comprehensive is his talk, "Values in Action: The Fox Project," paper presented at the American Anthropological Association, Chicago, 12/28/1957, subsequently published in Human Organization 17 (1958), 17-19. See also "Action Anthropology," American Indigena 7 (1952), 103-9. Tax and the literature in general referred to the project at the Meskwaki Settlement as the Fox Project, based on the name Sac and Fox, which whites applied to the tribe. In keeping with tribal preference, I use Meskwaki to refer to the community. 
The ideals of action anthropology attracted attention, but few practitioners, in the anthropological community during the 1950 s. Skeptics worried about the consequences for their field when social scientists abandoned their supposed stance of detachment from their objects of study. Typical was the stiff criticism that greeted Tax at an anthropology symposium in 1957, when colleagues discussing "Values in Action" pressed Tax to say whether he would be willing to help a group that wanted to practice cannibalism. ${ }^{2}$ Despite such criticism, action anthropology in many ways anticipated the critique of anthropology delivered in 1969 by Native American scholar Vine Deloria Jr., who urged Native Americans to refuse to be "objects of observation for those who do nothing to help us" and to demand that the "ideological vultures" do something to help the communities in which they wished to work. ${ }^{3}$

A half-century after the project began, action anthropology is little remembered within its field. One historian of anthropology, John Bennett, placed Tax among "the opening guns of the rebellions in the ranks of anthropology in the 1960s and 1970s," when some anthropologists began to attack the colonial roots of their field and the lingering vestiges of that past. Yet Tax did not receive credit for helping to foment that rebellion; the 1960s and 1970 s critique of anthropology was, according to Bennett, only "reminiscent" of action anthropology. George Stocking Jr., another historian of anthropology, also denies that Tax and action anthropology had any influence or impact on anthropology in general. Noting that action anthropology was "kept at the margins," Stocking uses the term resonance to describe Tax's relationship to the field. ${ }^{4}$

2. Robert Redfield, "Values in Action: A Comment," Human Organization 17 (1958), 20-22; Conrad Arensberg, "Values in Action: A Comment," ibid., 25-26. The entire 1957 symposium, sponsored by the Wenner-Gren Foundation, focused on action anthropology and other approaches to mixing academic work with service to the public.

3. Vine Deloria Jr., Custer Died for Your Sins: An Indian Manifesto (New York, 1970), 83-104; quotations are from pages 98 and 99.

4. John W. Bennett, "Applied and Action Anthropology: Ideological and Conceptual Aspects," Current Anthropology 36 (1996), S24, S37-38; George W. Stocking Jr., "Do Good, Young Man: Sol Tax and the World Mission of Liberal Democratic Anthropology," in Excluded Ancestors, Inventible Traditions: Essays To- 
Other scholars have found action anthropology's impact to have been negligible even within the confines of the Meskwaki Settlement. After Elizabeth Hoyt visited the community in the early 1960s, she wrote an article stressing the failures of the project-the impending bankruptcy of the tile-making business and the inadequate funding of a scholarship program. Larry R. Stucki found that the project lacked continuity, both in personnel and programs. He compared the researchers to "do-gooders" who are at first enthusiastic about helping a community and then move on to greener pastures after finding the situation more difficult than they expected. The project, he concluded, failed to live up to its goal of creating programs based on what the Meskwaki wanted. Most recently, Douglas E. Foley described the project as "a tiny blip in the long flow of Mesquaki history," although he credited its scholarship program with starting a trend of Meskwaki attending college. Summarizing the Meskwaki reaction to the project as "a wry, humorous, detached yet generous view," Foley generally submerged the voices of individual Meskwaki in favor of an attempt to arrive at a single communitywide assessment. $^{5}$

All of these scholars are correct that the project did not fully achieve all of its goals. Yet that does not mean that the project was without value. Action anthropology as carried out on the Meskwaki Settlement consisted of more than its most visible projects, the Tamacraft business and a scholarship program for youth. Settlement residents who are old enough to remember the researchers recall that the project had a profound impact on some individuals, and through them, on the community. There-

ward a More Inclusive History of Anthropology, ed. Richard Handler (Madison, WI, 2000), 254-55. For an overview of the critique of anthropology from the 1960s and 1970s, see Current Anthropology 9 (1968), 391-407, especially Gerald D. Berreman, "Is Anthropology Alive? Social Responsibility in Social Anthropology," 391-96.

5. Elizabeth Hoyt, "The Children of Tama," Journal of American Indian Education 3 (October 1963), 15-20; Larry Stucki, "Anthropologists and Indians: A New Look at the Fox Project," Plains Anthropologist 12 (1967), 300-17; Douglas E. Foley, "The Fox Project: A Reappraisal," Current Anthropology 40 (1999), 171-83; quotations on 179-80. Foley's insightful book, Heartland Chronicles (Philadelphia, 1995), also touches on the Meskwaki experience with action anthropology, but deals primarily with race relations between Tama whites and settlement residents. 
fore, a review of the Meskwaki experience with action anthropology from the viewpoint of the people themselves and taking into account a broader range of its activities is overdue.

Interviews with Meskwaki old enough to remember the project and a close reading of the field notes and correspondence of the Chicago students show that the Meskwaki response to the Chicago project was complicated and contradictory. For some settlement residents, the Chicago students were a novelty, role models, and mentors, and represented the Meskwaki's first opportunity to get to know white people personally. For others, the students were nosy outsiders bent on making a living from Meskwaki cultural capital. In the 1940s and 1950s, settlement residents responded selectively to the researchers and their ideas, and that colors their memories of the project fifty years later. ${ }^{6}$

THE CHICAGO PROJECT began in June 1948 as a fieldwork training experience for six graduate students from the University of Chicago's Department of Anthropology. Sol Tax, professor of anthropology at the University of Chicago, was put in charge of the summer-long training program, most likely because he had done research at the settlement in 1932 and 1934 for his dissertation on the Meskwaki kinship system. A native of Milwaukee, Tax grew up in the city's early twentieth-century socialist milieu. He absorbed many of the socialists' beliefs regarding the need to protect the common people from powerful capitalist interests. Even as a youth, Tax later reflected, "my emotions were quickly aroused by thoughts of social injustice, violence, war." Later, he spent a summer working at the Laboratory of Anthropology field institute under the direction of Ruth Benedict, who referred to Tax as one of the "crass young reformers" in the group.?

6. During the summers of 2001 and 2002, with the assistance of a research grant from the State Historical Society of Iowa, I conducted 25 oral history interviews with residents of the Meskwaki Settlement. I use pseudonyms for Meskwaki individuals, except in the case of a well-known artist.

7. Bennett, "Applied and Action Anthropology," S24, S37-38; Sol Tax, "Last on the Warpath: A Personalized Account of How an Anthropologist Learned from American Indians," copy of chapter in folder 2, box 273, Sol Tax Papers, Regenstein Library, University of Chicago (hereafter cited as STP); Benedict quotation from Margaret Mead, An Anthropologist at Work: Writings of Ruth Benedict (New York, 1973), 317. 
Tax, however, had few opportunities to put any reformist views into action after receiving his doctorate in anthropology from the University of Chicago in 1934. Immediately after earning his degree, he headed to Guatemala and Mexico, where he worked until returning to the University of Chicago in 1944. Even while out of the country, Tax was well aware of the beginnings of efforts to bring anthropologists out of their stances as detached observers and involve them in the problems of the world. Several of Tax's friends, including John Provinse and Morris Opler, found jobs with the Bureau of Indian Affairs after Commissioner John Collier began his Applied Anthropology Unit in 1936. After much soul-searching, Tax turned down a chance to work for the Inter-American Affairs Office in the U.S. Commerce Department during World War II, mostly because he did not want to give up academic work. ${ }^{8}$ Thus, the students who arrived at the Meskwaki Settlement in June 1948 were working under a professor who had harbored idealistic notions about doing good in the world, but had had few opportunities to put them into practice.

The graduate students found a Meskwaki Settlement far different from the one that exists today, with the new housing, automobiles, and other signs of prosperity brought by the tribe's gambling casino. In 1948 a community of about five hundred Meskwaki lived on a 3,253-acre enclave located a little more than a mile west of Tama in east-central Iowa. Settlement residents maintained a way of life that remained distinct in many of its values and beliefs from the way of life of the whites surrounding them, yet also overlapped with it in many ways. All around the settlement, white farmers worked their farms, but little Meskwaki land was suitable for farming (and few people were interested in it). Instead, many Meskwaki had blue-collar jobs in nearby towns. Yet unemployment was common and incomes were low, and those who had not served in

8. Robert A. Rubinstein, ed., Doing Fieldwork: The Correspondence of Robert Redfield and Sox Tax (1991; reprint, New Brunswick, NJ, 2002), 7-8, 11; Robert Lee McMillan, "Study of Anthropology: 1931-1937, at Columbia University and the University of Chicago" (Ph.D. diss., York University, 1986), 158-60; Ted Stevens to Robert Redfield, 5/27/1942, folder 10, box 34, Robert Redfield Papers, Regenstein Library, University of Chicago. 


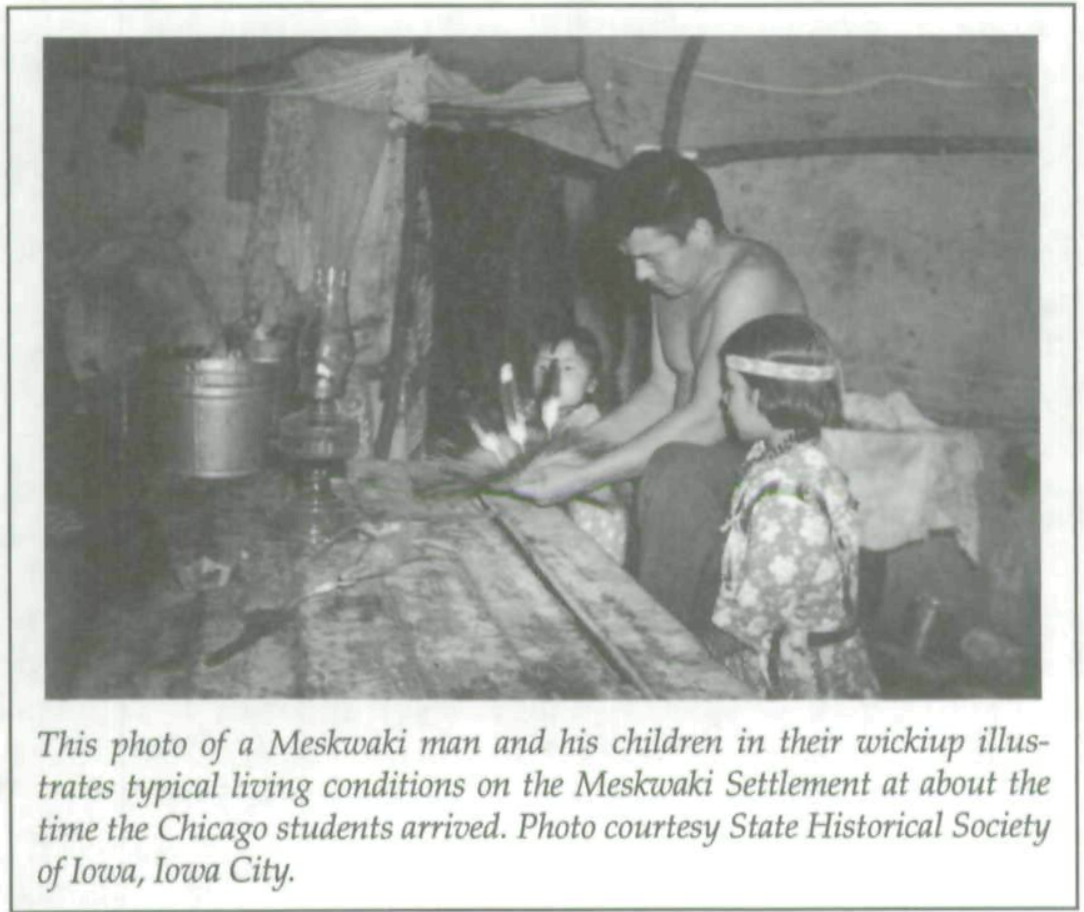

the military or did not work in town had little contact with whites. The Bureau of Indian Affairs did little for the people except run the settlement's day school and arrange for medical care through a contract with a local doctor. Settlement residents possessed one important asset, their land, which their ancestors had purchased in 1857 after trickling back from a Kansas reservation to which the federal government had sent them. The Meskwaki land purchase conferred on the Meskwaki the status of communal landowners, unlike most Indian communities whose reservation land was owned by the federal government. ${ }^{9}$

9. John B. Keliiaa, "Report of a Survey of Possibilities of Withdrawal of Federal Supervision and Services in Affairs of the Sac and Fox Indians of Tama, Iowa," August 1951, box 288, reel 4, frames 3027-70, STP. For population, see frame 3032; information on land, 3034-36; employment, 3041-42; school and health services, 3043 and 3047 . The report notes that some of the best Meskwaki farmland was leased to white farmers and the income used to pay taxes on settlement land. The report gives 1854 as the date for the land purchase, but 1857 was the effective date of a state law, passed in 1856, that granted the Meskwaki permission to live in the state. See Sac and Fox Sub-Agency, Toledo, Iowa, 
During the first summer, the graduate students lived in the day school on the settlement, while Tax made periodic visits from Chicago and kept in touch through letters and copies of the students' field notes as well as occasional telephone calls. Over the years, the interaction between the student anthropologists and the Meskwaki transformed the project from a onesided attempt by academics to exploit the Meskwaki's knowledge to a mutually beneficial relationship characterized by giveand-take and an exchange of services, which Tax eventually began calling "action anthropology." As Tax conceived it, action anthropology meant seeking both to study a community and to try to help its members meet goals they set for themselves. ${ }^{10}$

Tax continued sending students to the Meskwaki Settlement until 1958. Over the ensuing decade, settlement residents got to know especially some of the long-term visitors, such as Fred and Marjorie Gearing, Steve Polgar (who spent two summers on the settlement), and Robert Rietz, who was in the initial group of students and closed out the project in 1955-1958. After the first summer, Tax persuaded the university to buy a 58-acre farm and farmhouse just outside the settlement, where students learning fieldwork techniques could stay for the summer.

ANTHROPOLOGISTS had visited the Meskwaki Settlement long before the Chicago students arrived. Harvard University student William Jones, a member of the Sac and Fox tribe of Oklahoma, came in 1897 and was well received, but afterward some Meskwaki were annoyed that he published the tribal stories that people had told him. ${ }^{11}$ Another anthropologist, Truman Michelson from the Bureau of American Ethnology, had visited the community every summer for 18 years beginning in 1913 and hired members of the Meskwaki community to tell him about the

\footnotetext{
"Reservation Over-all Program," box 288, reel 4, 3002-4, STP; and Sac and Fox Tribe of the Mississippi in Iowa, Visitor Information Guide, undated, copy in author's possession.

10. Tax, "Action Anthropology," 103.

11. Henry Milner Rideout, William Jones: Indian, Cowboy, American Scholar, and Anthropologist in the Field (New York, 1912), 7, 15, 17, 44-45; and Johnathan Buffalo, Meskwaki tribal historian, quoted in paper, "William Jones," by an unnamed Meskwaki student, undated, copy in author's possession.
} 
tribe's culture. While some Meskwaki benefited from Michelson's ability to pay them for information, others resented his prying into what they considered to be private, sacred matters. Anyone who worked for Michelson risked criticism from neighbors as one who "would sell his birthrite [sic] for money." Others tried to impede Michelson's work by giving him false information. ${ }^{12}$

These types of Meskwaki responses to anthropologists anticipated the complaints that Vine Deloria Jr. expressed four decades later about the value of anthropology for American Indian communities. Not surprisingly, some of the same resentments surfaced in regard to the Chicago students. Young Meskwaki who had served in the U.S. military could be especially blunt about their feelings, and the graduate students recorded the Meskwaki's remarks, along with their own interpretations of them. One youth, Lawrence Phillips, greeted a student the first summer with the sarcastic remark, "Haa! Here's the fellow that's out here to study the Indians!" The student's field notes referred to Phillips as an "almost typical resentful ethnic," indicating how he had rebuffed the Chicago students. Another youth asked contemptuously, "Oh-come to study the Indians?" when he met the Chicago student. Sometimes, but not always, such remarks seemed to allow the individual to get the hostility off his or her chest and clear the way for a more pleasant conversation. ${ }^{13}$

Years later, one Meskwaki suggested that even when the anthropologists successfully engaged people in conversation, the information they exchanged may not have been accurate. Chad King recalled that some people would not tell the researchers what they really thought either because of language difficulties, because they were not used to talking to strangers, or because "they didn't think they needed to know." ${ }^{\prime 14}$

12. Truman Michelson, Contributions to Fox Ethnology, Bureau of American Ethnology Bulletin 85 (Washington, DC, 1927), 1:161-62; Fred Gearing field notes, undated, box 288, reel 4, frame 2267, STP; and Carol Wiesender field notes, 7 / $10 / 1949$, box 288 , reel 1, frame 458, STP.

13. Walter Miller field notes, $7 / 9 / 1948$ and 6/29/1948, box 288, reel 2, frames 253,257 , and 290, STP. "Lawrence Phillips" is a pseudonym.

14. Interview with the author, 6/26/2002, Meskwaki Settlement. Fred McTaggert had experienced a similar refusal to open up to researchers in 1970-71 when, as a University of Iowa graduate student in English, he tried, without 
Another Meskwaki recalled directly confronting researchers over the issue of being on the settlement to study the Meskwaki. Sally Deer said she asked one of the students several years into the project, "What good is anthropology anyway?" She was not surprised when he said nothing in reply. "What could he say?" Deer and others felt that over the years people on the settlement had helped students get their degrees. Those students then went away, leaving nothing behind for the people who had helped them. Deer wondered why only anthropologists and missionaries came to her community and not professionals with skills that would be useful, such as lawyers. She remembered the conversation with some bitterness and indicated that she had made the same remark several times and never got an answer. In fact, one of the students summarized in her field notes a remarkably similar discussion with Deer and her mother. As a student struggled to explain the anthropologists' presence on the settlement as a way to help people understand each other, Deer's mother asked, "I was wondering if you were going to write a book and make a lot of money off of it. My husband says we shouldn't tell white people our songs and stories because they make a lot of money off them and we don't get anything." 15

Other Meskwaki acknowledged the existence of such sentiment within the community then and now. Al White said the sentiment extends not just to anthropologists, but also to other scholars and news reporters. But many Meskwaki do not share this attitude. Lily Thomas said that some people "will just tell whites to get lost," but she considers herself to be "a nice person" who is willing to welcome scholars who treat her well. Al White added,

I suppose there were a few people that didn't want to talk to the anthropologists, just like now. There's a lot of people that won't talk to you. I don't know what the reasons are. . . . It might have

success, to collect folklore from settlement residents. See Fred McTaggart, Wolf That I Am: In Search of the Red Earth People (1976; reprint, Norman, OK, 1984), 1-5. 15. Interview with the author, 7/11/2001, Meskwaki Settlement; Davida Wolffson field notes, 7/7/1948, box 288, reel 2, frame 1395, STP. Another Meskwaki commented, "The white man's way is to take and take and take. The Indian way is to take and give back." Interview with the author, 8/16/2001, Meskwaki Settlement. 
been prejudice against white people making a lot of money. It's still around now. I suppose [it stems from] when Indians were being persecuted from way back. I don't feel that way. If they get lucky, they will make a lot of money, but it doesn't happen every time. I see it differently. If a person has the ambition to do it [gather information and write a book that sells well], they deserve it. ${ }^{16}$

The existence of such sentiments guaranteed the Chicago students an uneven reception from the Meskwaki, but other factors, such as individual circumstances, also affected the relationship. The presence of the researchers was only marginal to the life of settlement resident Charles Spotted Horse from 1948 to 1958. His mother had died when he was young, and his father gave him little support, so he spent much of his youth in the woods of the settlement shooting deer for food or trapping muskrat, beaver, or mink for skins to sell. Once, Bob Rietz hired him to mow the lawn at the project house, and Spotted Horse appreciated the pay. Otherwise, he had little contact with the students. He recalled other people on the settlement talking about them, but Spotted Horse, a self-described "loner," was not interested in their parties and dances. ${ }^{17}$

Even people who were friendly to the researchers-and there were many-had trouble understanding exactly why the anthropology students came back to the settlement year after year. Tax and the students told settlement residents that they were there to help them, but the statements were too vague to have much meaning. One man who generally was friendly with the students was puzzled by the university's decision to buy the farmhouse as a summer base for fieldworkers. Reasoning that the university would not "spend all that money for nothing," he wanted to know "what they expect to get out of it."18

Uncertainty about what the researchers were really up to remained even fifty years after the project ended. One man who was in his early twenties when the researchers were at the settlement expressed the confusion common among members of the community: "They didn't really say what they were here for.

16. Interviews with the author, $7 / 11 / 2001$ and 6/26/2002, Meskwaki Settlement.

17. Interview with the author, $6 / 13 / 2001$, Meskwaki Settlement.

18. Robert Rietz field notes, March 1949, box 288, reel 2, frame 586, STP. 
They were just here." He thought their goal might have been "to instill 'their ways' onto us," as so many missionaries and white do-gooders had attempted to do in the past. Another man thought their purpose was purely academic: "I think they were just studying us, our behavior patterns. ${ }^{\prime 19}$

THE STUDENTS did carry out observations of the Meskwaki for their anthropological work, but they also assisted in some small-scale community endeavors. During the summer of 1953, for example, Marjorie Gearing organized a group of girls into a cooperative that planted several acres of cucumbers and sold them to an Iowa canning factory. Although the girls planted, hoed, and thinned diligently in the hot sun, a dry spell cut their harvest and the girls were disappointed with their meager earnings for the summer's work. Fred Gearing helped reestablish the settlement's American Legion Post and remodel an old building to serve as a meeting place. Marjorie Gearing also helped young people plan a Halloween party for the community, a longstanding event planned and hosted each year by the young people on the settlement. To be chosen as the adult to help the youngsters put on the party was considered an honor. From 1948 on, the students also provided a variety of assistance to residents of the settlement on a day-to-day basis: use of the telephone, rides to town in the university car, and so on. ${ }^{20}$

The researchers' two-story farmhouse, with an outhouse in the back, was a dilapidated affair by white middle-class standards and required considerable improvements, including installation of a shower in the former root cellar, before it was ready for occupancy. For settlement residents living in tworoom houses without electricity in a community with few organized recreational opportunities, however, the house was a magnet. "We used to go up to that house and just talk and play games," recalled Richard Brave Heart. Other Meskwaki came

19. Interviews with the author, $6 / 28 / 2001$ and $6 / 12 / 2001$, Meskwaki Settlement. 20. Marjorie Gearing field notes, $7 / 27 / 1953,8 / 11 / 1953$, and $9 / 29 / 1952$, box 288, reel 5, frames 3131A-L, 3136-39, reel 4, 2291-95, STP. Marjorie Gearing was married to Fred Gearing and was not an anthropologist. 
for informal music sessions, bringing a guitar or recorder to accompany the researchers on trumpet or piano. ${ }^{21}$

One man stressed that "we had our own reasons for befriending them [the students]." Some Meskwaki came around mealtime and stayed to eat lunch or dinner. "I kind of enjoyed the fact that they fed me," Alexander Schneider said. Schneider never asked for anything because he said that would have been impolite, but when he stopped by the students often asked, "Hey, you want something to eat?" Even at other times the students often provided snacks or other refreshments, such as coffee, Kool-Aid, or candy. One man said that when he was a boy friends asked him why he went to the home of a minister at a Christian church, since settlement residents shunned Christianity. His reply: The minister's wife made great sloppy Joes. "If I sang a couple of hymns, it was just for the milk and cookies," he said, adding that his relationship with the students was similar. ${ }^{22}$

Meskwaki who were in their teens in the 1950s have especially vivid memories of the summer of 1952, when Chicago student Steve Polgar organized a group of boys to clean out a barn on the University of Chicago property to be used for a recreation center. While doing the work, Polgar took note of the boys' interaction for a study on the cross-cultural socialization of Meskwaki boys. Youth who showed up to help Polgar clean the barn sometimes informed him that they did not want to work but wanted to go swimming that day instead. Polgar would load up the station wagon and take them, following their lead in exchange for the opportunity to carry out his observations of them. As Tammy Riley recalled, "That old station wagon, there would be six to eight kids jammed in there." ${ }^{23}$

21. Report of Expenditures: Fox Field Party, 9/10/1949, folder: Miscellaneous Accounts 1948-1954, box 17, Fox Project Papers, National Anthropological Archives, Suitland, MD (hereafter cited as FPP); interview with the author, $6 / 2 / 2001$, Meskwaki Settlement. For Foley's brief treatment of individual interactions, see "The Fox Project: A Reappraisal," 179.

22. Interviews with the author, $7 / 12 / 2001$ and 6/12/2001, Meskwaki Settlement; Wolffson field notes, 7/6/1948, box 288, reel 2, frame 1623, STP; Polgar journal, 7/6/1952, box 288, reel 6, frame 4324, STP.

23. Three interviews with the author, 6/1/2001, Meskwaki Settlement. The article Polgar produced was "Biculturation of Mesquakie Teenage Boys," in American Anthropologist 62 (1960), 217-35. 
One Meskwaki man recalled the barn-cleaning experience as more play than work. William Van Dyke said, "I liked their project. They took us swimming and roller skating and took us all around, to Sportsman's Lake for picnics, swimming and stuff like that." The students willingly accommodated the wishes of the young people. "We used to tell them what we liked [to do]. We would tell them, give them input [on] what we liked. They would agree. . . . My parents, they were all for it. They thought it was a good thing for us kids to do." While adults at the time may have discussed weightier matters with the researchers, for Van Dyke, the project "was more a social club."24

Meskwaki youth suggested using the barn itself for dances. The square dances, box socials, and roller-skating parties at the barn provided many evenings of enjoyment for young people living in a cash-poor community. Many Meskwaki who are now adults remember the swimming and roller-skating parties as highlights of their summer. Remembering the dances in the old barn, Tammy Riley joked that the young people probably had more fun out behind the barn than at the activities or dances inside. $^{25}$

Richard Brave Heart, another Meskwaki man who helped on the barn project as a teenager, said the youth pitched in on the project of their own accord because they had come to like Polgar so well. "You'd just do it, clean it. We were doing it out of respect for them," he said. He remembered Polgar and the other Chicago people as down-to-earth people. "It wasn't hard to get to know them," he said. Although Polgar asked the boys questions for his study, Brave Heart said that never interfered with the good times they had. "Sometimes, he would ask a question about my personal life, how many sisters you had, blah, blah, blah," he said. None of the questions was insulting or improper, he said, adding that at his age, "you just didn't realize about those things." When Brave Heart grew older, he remembered how much the activities organized by Polgar and the others had meant to him. "I think it was good for the kids. There wasn't anything to do [otherwise]," he said. He credited

24. Interview with the author, 6/1/2001, Meskwaki Settlement.

25. Three interviews with the author, June 1, 2001, Meskwaki Settlement. 
the memories of those times with influencing his decision to become active in organizing recreational activities, such as baseball, boxing, flag football, and volleyball, for current settlement youth. ${ }^{26}$

On a personal level, many of the young people related well to the researchers. Van Dyke, for example, enjoyed Polgar's company because "you could become friends with him very, very easily. He was very warm, humorous. It seemed like people were always teasing him and he was able to tease back. He wasn't shy." Another man said he would sit and talk with Rietz for hours "about everything and nothing.,"27

Even people who expressed hostility toward the anthropologists were ambivalent about the years the researchers spent on the settlement. Despite her reluctance to see outsiders make money and advance their careers off of Meskwaki, Sally Deer maintained friendly relations with some of the women in the field parties. Deer said she socialized with women members of the field parties because there were few other diversions in those days for a mother at home all day with young children. For years, she maintained a correspondence with Marjorie Gearing, in part to keep Gearing up on news of Deer's family and other people on the settlement, and in part because she enjoys writing letters. Deer also made and appliquéd an apron, which she gave to one of the researchers, Grace Gredys. Fifty years later, Gredys still had the apron, which she never used but kept in her kitchen as a reminder of how touched she was that Deer had made it for her. ${ }^{28}$

The presence of the anthropologists meant more than good times. Wendy Schmitz, who was married with children when the researchers arrived, found their company intellectually stimulating. "I learned a lot about the outside world, rubbing shoulders with professors. Mr. Rietz was a teacher to me, [teaching me] how other people lived, their experiences," she said. For years afterward, Schmitz corresponded with some of

26. Interview with the author, $6 / 2 / 2001$, Meskwaki Settlement.

27. Interviews with the author, $6 / 1 / 2001$ and $7 / 12 / 2001$, Meskwaki Settlement.

28. Interview with the author, $7 / 11 / 2001$, Meskwaki Settlement; interview with the author, 10/23/2002, Rochester, New York. I interviewed four former students and associates of Tax, but some, including Rietz and Polgar, had died. 


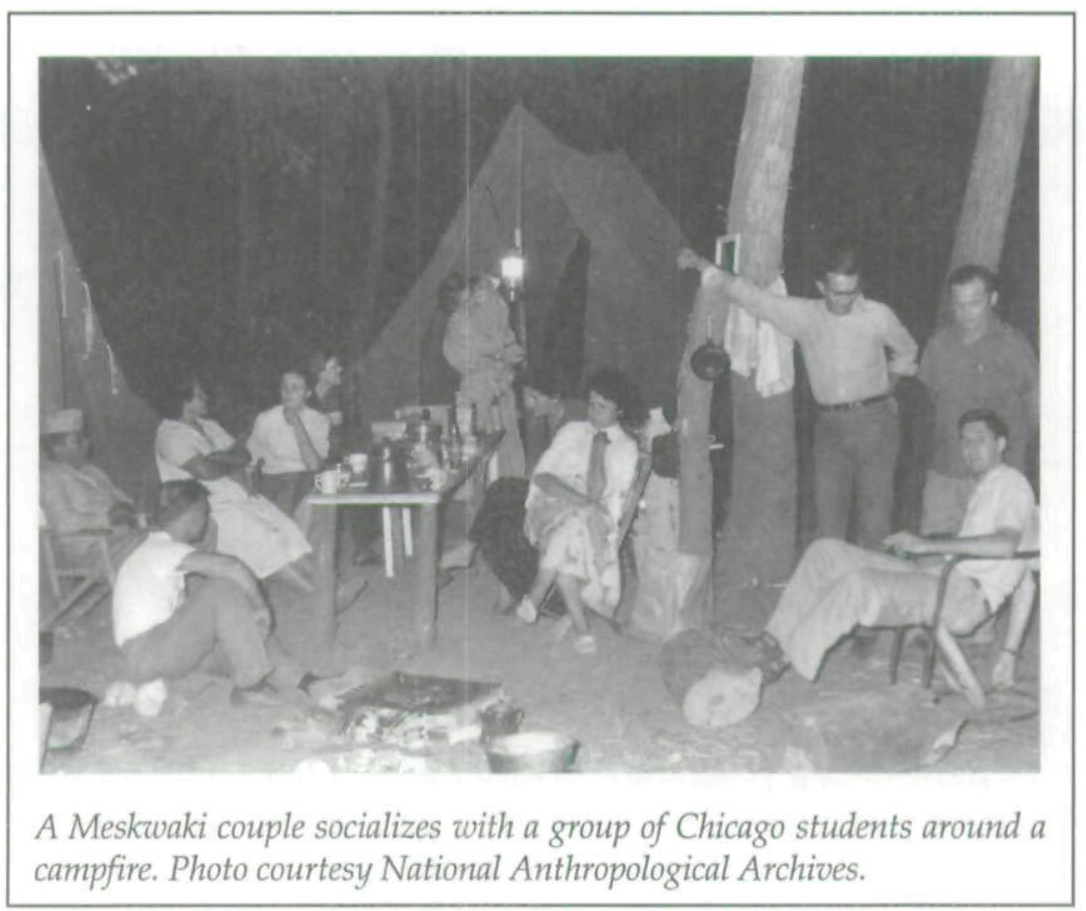

the women involved in the project. "I miss their friendship, just being able to talk with them and learning their side of the world, their travels," she said. ${ }^{29}$

For some people on the settlement, the students were the first white people they really got to know. Except for military veterans, settlement adults who did not attend high school in Tama or have a job off the settlement often had had little contact with whites. As one woman put it, "They taught me that there are some good white people." Van Dyke saw the relationship as a chance for growth on both sides: "They understood the Indians a little more. We understood the white folks a little more." The relationship even helped Van Dyke understand his own heritage better. If one of the students asked him a question about some aspect of Meskwaki culture that he did not know about, he often went to his parents to get the answer. ${ }^{30}$

29. Interview with the author, $6 / 1 / 2001$, Meskwaki Settlement.

30. Interviews with the author, $8 / 12 / 2002$ and 6/1/2001, Meskwaki Settlement. 
For some Meskwaki, getting to know the researchers was a life-changing experience. Lisa Fredericks, daughter of Henry and Alice Carter, visited the anthropologists almost nightly with her parents and remembers eating supper there and then listening to the adults talk about the settlement's politics and future, as well as other topics. During one period, she was depressed over the death of her grandmother. One of the students made a special effort to talk to her about her feelings and, over a period of time, helped bring her out of her depression. ${ }^{31}$

Contact with the Chicago people also broadened the horizons of Lisa's mother. At the urging of Robert Rietz, Alice Carter ran for tribal council in 1957. She campaigned actively and was elected, becoming the first woman to serve on the council. "My mother broke the door open for other women on the council," said one of her children. "In the old days, only a privileged woman who did a great deed got the chance to speak in the council." Besides serving two terms on the council, Alice Carter chaired the tribal school board, became the first woman to serve on the tribal powwow committee, and served on the Iowa Arts Council's Artists in the Schools Program. In 1993 she was inducted into the Iowa Women's Hall of Fame. ${ }^{32}$

Cathy Arrow, who also knew the researchers well, credited them with transforming her attitude toward herself. Her tall, thin frame made her feel awkward and increased her already shy demeanor. One of the women in the group told Arrow not to be ashamed that she was tall but to take pride in it. Her talks with the researchers improved her self-esteem and taught her to think about the world beyond the settlement. "I realized there was something besides being poor and rugged and ragged and hungry," she said. Married with small children, Arrow and her family were extremely poor, even living in a tent, because her husband was unable to keep a job. With the encouragement of the anthropologists, in about 1954 Arrow and her children moved to Chicago. Once there, the anthropologists provided

31. Interview with the author, $7 / 24 / 2001$, Meskwaki Settlement.

32. Rietz to Tax, 11/17/1957, folder: Tama 12 (2 of 2), box 9, FPP; interview with the author, 6/26/2002, Meskwaki Settlement; Iowa Women's Hall of Fame Program, 8/23/2003, Iowa Commission on the Status of Women, www.state.ia.us/dhr/sw/pdf/HoFBook03.pdf, 39. 
emotional support and friendship and taught her how to be "an urban person." Simply knowing someone in the city who would call and suggest that they do something together eased the transition for her. Arrow got a job in the dietetic office at the University of Chicago. At first, she dressed plainly, but her anthropologist friends persuaded her to dress up and wear pumps and, as Arrow put it, to feel that "I could be somebody." Arrow spent ten years in Chicago before moving to Colorado to take a job in social work. After retiring, she returned to the settlement, where she is a respected elder. ${ }^{33}$

This dense background of interpersonal relationships formed the foundation for the action anthropology projects. As interviews with Meskwaki show, the foundation had its solid parts, as well as its weak spots and even cracks. People who did not like outsiders prying into Meskwaki business were unlikely to be satisfied with the researchers' projects no matter what shape they took or what success they had. Those who forged strong ties to the Chicago people were in a better position to influence the direction the action anthropology projects took and to enjoy the outcome. Even such generalizations, however, had their exceptions.

ENTERTAINING THE TEENS, reestablishing the American Legion post, and undertaking similar projects were welcome endeavors on the Meskwaki Settlement, but the anthropologists' rhetoric outstripped those accomplishments. The visiting students had told settlement residents repeatedly that they wanted to help them, but the promises were never concrete. Acknowledging the need to do something visible, Steve Polgar noted "the many precedents of anthropologists coming out here and never actually doing something for the Mesquakie, beyond distributing lemon drops to the kids and tobacco to the old people, or paying experts for their dishing out of 'facts."' Yet the researchers also were acutely aware of the limits of what the project could do for the settlement. In 1952 Polgar warned against raising people's expectations too high with assurances of assistance. The researchers, he said,

33. Interview with the author, 8/16/2001, Meskwaki Settlement. 
must make it clear to the Mesquakie that we can do just so much and no more, we must make it clear what our own interest is, convincing the[m] that we do not look upon them as animals in a zoo, or experimental rabbits. ... In face of the deep-seated suspicion, and the desire to use us for their own ends, we have to be very honest and straightforward. We have to lay a groundwork of deep personal friendships, through which such honesty can be displayed without fear of alienating the people and losing objectivity.

Polgar's instincts were correct. After several years of visits by Chicago field parties, members of the community dropped hints "that it was time the UC began producing."

Tax and the students were unable to produce much until after 1954, when Tax secured a four-year, $\$ 60,000$ grant from the Emil Schwartzhaupt Foundation of Santa Cruz, California, founded to promote education for citizenship, broadly conceived. ${ }^{35}$ Although scholars such as Larry Stucki and Elizabeth Hoyt later accused Tax and the anthropologists of designing a program and foisting it onto the Meskwaki community, project records reveal that the settlement residents did wield influence over the programs that were started, especially in the case of the two most visible aspects of action anthropology: the crafts program and the scholarship program.

In his application to the Schwartzhaupt Foundation, Tax had proposed a program designed to help the Meskwaki handle their own affairs. Congress in the 1950s was attempting to force Indians to assimilate into the white American mainstream by following a policy called termination. That policy, expressed in House Concurrent Resolution 108 passed in 1953, tried to eliminate federal responsibility for American Indians by withdrawing services to tribes, transferring responsibility for them from the Bureau of Indian Affairs to other federal agencies or to states, and dissolving the tribes as legal entities. Tax opposed that policy, but he did believe that the Meskwaki and other Indian peoples ought to be able to run their own schools and health care

34. Steve Polgar field notes, 6/22/1952, box 288, reel 6, frame 4316, STP; Polgar journal, 6/22/1952, ibid.; Fred Gearing field notes, August 1952, box 288, reel 4, frame 2257, STP.

35. "The Tama Project: A Proposal Submitted for Financing," 5/15/1954, folder: Proposals, Reports, Memos, Schwarzhaupt [sic] Foundation Report, box 5, FPP. 
programs while receiving federal subsidies. His plan for the Meskwaki Settlement was to help the residents set up their own community center and health clinic, as well as to work with them and a group of Tama whites on radio and television programs to educate each group about the other's culture. The proposal was based on informal conversations with settlement residents, especially those families such as Henry and Alice Carter to whom the anthropologists were especially close. ${ }^{36}$

Before those plans could be put into effect, however, Tax changed course because, as he put it, "the opportunity arose" to establish a small business on the settlement. Apparently, "the opportunity arose" from individual Meskwaki themselves. ${ }^{37}$ As early as 1949, a settlement resident had told one of the graduate students, Robert Rietz, about his attempts to organize an arts and crafts cooperative a year earlier. Many Meskwaki did beadwork and made various souvenirs that they sold to tourists, but they did so as individuals and competed with each other to sell the items at fairs and powwows. The idea behind the cooperative was to buy supplies together to cut costs and to coordinate sales rather than compete.

Nothing developed from that lead until after Rietz returned to the settlement in 1955 with the Schwartzhaupt funding. One day in October, Rietz stopped at the home of a Meskwaki artist, Charles Pushetonequa, to buy one of his paintings. Rietz joked that they should put together a paint-by-numbers kit so the public could make their own versions of Pushetonequa's work. In Rietz's jest, Pushetonequa saw the chance to create a project that could benefit the entire community. Rietz and Pushetonequa launched an arts and crafts cooperative called Tamacraft. Pushetonequa drew the pictures and picked out colors for the kits while Rietz bought the supplies. Within two months, 11 Meskwaki had joined the cooperative to make the paint-bynumber kits. They soon branched out to silk-screening Christ-

36. Ibid.

37. "The Schwarzhaupt [sic] Foundation Tama Indian Program Report of Activities, 1955-56," February 1957, folder: Proposals, Reports, Memos, Schwarzhaupt Foundation Report," box 5, FPP, 3.

38. "Copy of Document," September 1949, folder: Sol Tax et al. Economics, Rietz, box 8, FPP. 
mas cards and later making ceramic tiles. Other community residents began helping out in the production, although they did not formally join the cooperative. Sales grew slowly, but in 1956 the group sold $\$ 3,000$ worth of craft items. ${ }^{39}$ Eventually, the cooperative sold Tamacraft products not just locally, but in other parts of the country, especially the Southwest and in some national park gift shops. ${ }^{40}$ Although the Bureau of Indian Affairs had a program to encourage Indian arts and crafts, the Meskwaki project seemed to have little relationship to it. When Tax arranged to have Meskwaki products sold in national park gift stores, he wrote directly to the National Park Service rather than going through the Bureau of Indian Affairs crafts program. ${ }^{41}$

Financial records for Tamacraft are sketchy, but for a time the small cooperative appeared to be on the verge of something bigger. In order to advertise and buy better equipment to cut production costs, Rietz arranged for Tamacraft to receive a $\$ 6,000$ loan from the project's Schwartzhaupt grant in the fall of 1956. Tax thought that if the federal government's termination policy came to fruition, settlement residents, whose formal business ties with outsiders had been limited to renting some of their land to farmers for cash to pay their property taxes, would need to know more about white ways of doing business. Therefore, he rationalized the loan on the grounds that a successful arts and crafts cooperative run in keeping with Meskwaki values would increase people's self-confidence and skills for dealing in the white business world, while reassuring them that adopting some white practices would not threaten their own culture. At the same time, such a venture would earn them respect among their white neighbors. Mindful of the grant application's goal of making the Meskwaki better citizens in charge of their own

39. "Chapter III: Action Anthropology as Field Program," undated, box 12, FPP, $61-66$. The $\$ 3,000$ in sales would be equivalent to $\$ 20,283$ in sales in 2003 dollars. See inflation calculator at the U.S. Bureau of Labor Statistics Web page, www.bls.gov/cpi/.

40. For examples of places where Tamacraft products were sold, see monthly accounts receivable statements for December 1959, January 1960, and February 1960, folder: Sol Tax et al. Tamacraft and Schwartzhaupt Accounts, box 11, FPP.

41. Tax to Jean C. Harrington, National Park Service, 2/9/1955, folder: Sol Tax et al., G-H, box 9, FPP. 


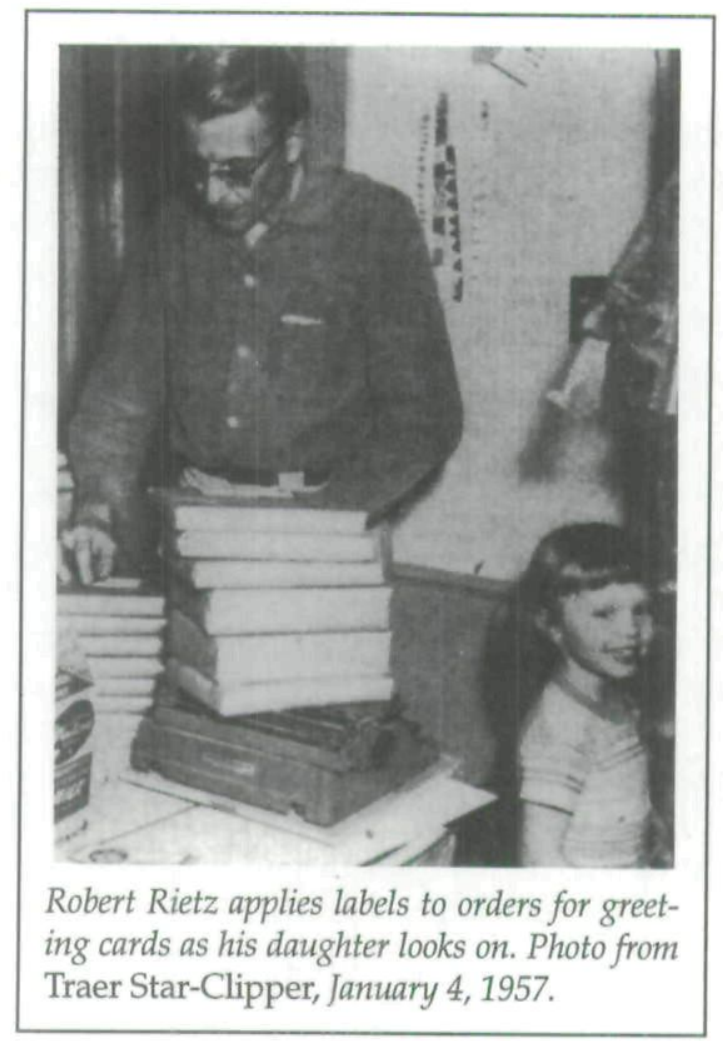

affairs, Tax also said that a thriving business would "hasten the day when the Indians will administer their own vital community services" rather than relying on the government. Tax saw preparing the tribe for self-determination, not producing greeting cards, as the main purpose of Tamacraft. ${ }^{42}$

One man remembered how Tamacraft operated. "Each person owned a piece of the action. . . . The more they produced, the more money they would have made," he said. Rietz helped solicit orders. At one time he had a stack of unfilled orders eight inches high, so he recruited new people to learn how to silkscreen. "We never were salaried," recalled one woman. "We always just put it back into materials." Instead of receiving cash for their work, co-op members built up equity in the business.

42. "Chapter III: Action Anthropology as Field Program," 66-67. 
After five years of operation, total worker earnings amounted to $\$ 10,589$, but much of it was unpaid. ${ }^{43}$

The existence of Tamacraft stirred interest in the settlement among white civic leaders in nearby Tama. In the 1940s, Tama County Attorney Walter J. Willett had persuaded Congress to let the county enforce state criminal laws on the settlement by depicting the community as a lawless no man's land. After the Meskwaki started Tamacraft, however, Willett suddenly saw the settlement as a potential asset to the Tama area. He pushed a Chamber of Commerce plan "to build a big celebration around the Indian Powwow each year. Business people would dress up like Indians to give the tourists more 'atmosphere.'" Chamber members dreamed of attracting twenty to thirty train cars filled with tourists from Chicago who would come to experience an exotic Indian spectacle just a short trip from home. The annual powwow, organized by a committee of Meskwaki, already attracted several thousand visitors, mostly from outside the local area. Willett's proposal was a turnaround for the chamber, which previously had limited its involvement to contributing $\$ 100$ for advertising the event. To show its support for Tamacraft, the chamber bought Tamacraft's ceramic tiles to give as gifts to farmers attending meetings at the Pioneer Seed Corn Company in nearby Toledo. ${ }^{44}$

Meskwaki people did not buy into the chamber's proposal to have retailers dress up like Indians to promote the powwow. Soon, however, Tama whites came up with an even more threatening proposal-that whites take over management of Tamacraft. As the Schwartzhaupt grant neared its end in 1958, Rietz prepared to transfer to Chicago to become director of the American Indian Center in Chicago, established to help Indians who had relocated to Chicago under the Bureau of Indian Affairs' relocation program. Convinced that Tamacraft would go

43. Interviews with the author, 6/13/2001 and 6/1/2001, Meskwaki Settlement. Based on the U.S. government Bureau of Labor Statistics inflation calculator at www.bls.gov/cpi/, the proceeds amounted to $\$ 65,788$ in 2003 dollars. According to Keliiaa, "Report," frame 3042, the average annual income from employment per family on the settlement for the twenty-month period ending March 1951 was estimated at $\$ 1,000$ per family.

44. Tama News-Herald, 1/16/1958; Keliiaa, "Report," frame 3046. 
bankrupt as soon as Rietz left, Tama whites lobbied him to turn the business over to white managers or even to allow whites to buy a controlling interest in the operation. Rietz rebuffed their efforts and left the settlement in June 1958 with Tamacraft securely in Meskwaki hands. ${ }^{45}$

Sol Tax had little to do with Tamacraft for the next four years until an Iowa State College economist wrote to him about a recent visit she had paid to the settlement. Elizabeth Hoyt said that when she stopped at the Tamacraft headquarters, a woman told her that the enterprise was in financial trouble, people had not been paid for their work, and orders were not being met. According to Hoyt, whites from Tama still were trying to take over Tamacraft, and settlement residents feared that Rietz would give in to them. ${ }^{46}$

While acting as director of the American Indian Center in Chicago, Rietz continued to keep records for Tamacraft and helped procure supplies, find new customers, and so on. Meanwhile, Tamacraft workers decided to pay themselves wages rather than pay commissions to their sales representative in western states. As a result, wholesale orders slumped, and, Rietz reported, "the crafts project is going downhill fast and will eventually bankrupt itself, if its present direction continues." He added that the decision on whether to let whites take over ownership of Tamacraft was up to the Meskwaki, not him, but he hoped that they would refuse. He admitted, though, that the only alternative to white control was an outsider who would offer advice but let the people involved in it run the operation. Unable to find such a person, Rietz suggested in a letter to Tax that Hoyt might be interested in taking on that responsibility. ${ }^{47}$

Hoyt had no such interest, especially since she misread Rietz's letter to suggest that she take over Tamacraft while letting the Meskwaki think they were still in charge. Her interest was in writing an article about Tamacraft that would contradict Tax's speeches at anthropological meetings praising the opera-

45. Rietz to Tax, 9/14/1957 and 3/29/1958, folder: Sol Tax, et al., Tama 12 (2 of 2), box 9, FPP.

46. Hoyt to Tax, 10/12/1962, folder 4, box 126, STP.

47. Rietz to Tax, 10/14/1962, ibid. 
tion. Hoyt found that Meskwaki felt exploited by the University of Chicago research project. In a letter to Tax, she quoted one woman as saying, "Are you also coming with false promises? I suppose you have a lot of money to make this study, but are you going to deceive us? Before I answer any questions, I want to know that." Furthermore, Hoyt, based on an isolated statement she found in a history of the project compiled by the researchers, accused the action anthropologists of having disparaged settlement residents and trying to manipulate them. ${ }^{48}$

Hoyt went on to write both a journal article and a book about the Chicago anthropologists' project with the Meskwaki. In her book, Tama: An American Conflict, Hoyt accused the researchers of designing a plan and pretending it was what the community residents wanted. At the same time, however, she criticized the researchers for being too candid in the history of the project that they compiled. She said that the document showed the Meskwaki that "they had been the purposive subjects of experiment. ${ }^{\prime 4}$

48. Hoyt to Tax, $1 / 15 / 1963$, ibid. The statement that Hoyt focused on concerned an effort by Fred Gearing to start a Meskwaki farming cooperative for the 1953 growing season. Gearing had recruited several settlement residents to take part and was trying to line up business or government support for the project, although the group intended to go ahead whether that help materialized or not. Gearing and the potential co-op farmers, however, had not been working through the tribal council to set up the project, on the grounds that the project was not a community-wide endeavor but one involving only four people. Because the co-op members were from a different political group within the settlement than the council majority, Gearing apparently feared that the council would try to block the project. To prevent that, he came up with a plan to inform the council about the project when it was still in its formative stages, but give the impression that it was so far along that it could not be stopped, although future developments in the project still could be modified based on council suggestions. The statement Hoyt singled out was, "The thing must be presented to them [the council members] as something of a fait accompli and at the same time they must feel that they are truly being consulted." See Gearing to Bert Stolpe, 12/8/1952, in Gearing et al., eds., Documentary History of the Fox Project, 1948-1959 (Chicago, 1960), 210-12.

49. Elizabeth Hoyt, Tama: An American Conflict (Ames, 1964). This book of Hoyt's was published only as 50 mimeographed copies. Hoyt sent a draft copy to Tax for comment. The journal article was published as "The Children of Tama," Journal of American Indian Education 3 (1963), 15-20. Hoyt also faulted the scholarship program and Tamacraft enterprise as having only a "weak" grounding in economics and said an economist should have been called in to teach the Meskwaki how to run a business. Hoyt, "Children of Tama," 17-20. 
Tax was furious when he saw Hoyt's work. He wrote to his former students about the "nasty things" she had written about the project and asked Rietz to write a reply. In addition, he pressured the Wenner-Gren Foundation for Anthropological Research to contact Hoyt and work with her to send the work to other anthropologists who would comment on it, in much the same way that the anthropology journal Current Anthropology did with the articles it published. ${ }^{50}$ To Hoyt, Tax wrote, "You will be disheartened now to know that you have inadvertently libeled my students, me, and the University." In a long letter to Hoyt, Tax defended the researchers as having made sincere efforts to help individuals, if not everyone in the community. He wrote,

Tamacraft helped a few-it was never intended to be a wholecommunity cooperative; the scholarship program helped a few; both I hope indirectly helped the whole. We would have liked time and energy for many enterprises like Tamacraft and the scholarship program; but as you know even these overtaxed us. But even if we had done much more and helped more people at the level we did, resentment of others might have overweighed the mixed feelings of those helped.

Tax said that the experience with the Meskwaki taught him how difficult social problems were to solve, and he admitted that "even social science well applied cannot do much. ${ }{ }^{51}$

The ruckus Tax raised over Hoyt's writings seems justified from a professional point of view. Her work sounded amateurish. Many of her points were based on references to Indians in general. While purporting to exhibit an understanding of settlement thinking, Hoyt viewed the community members as monolithic in their thinking; she did not allow for nuances or differences in opinion. Her shallow approach to the community

50. Tax to Gearing, 1/15/1964, folder 4, box 126, STP; Hoyt to Tax, 1/15/1963, ibid. Hoyt's letter referred to "the booklet from the Wenner-Gren Foundation, sent out under your direction, and the suggestions for response from Associates." The file contained no correspondence from Tax to the foundation regarding the matter. Wenner-Gren had provided funding in 1958 to start Current Anthropology, with Tax as its editor. As editor, Tax pioneered the practice of precirculating articles to qualified anthropologists and publishing the article, the readers' responses, and replies from the author in the same issue. See Robert A. Rubinstein, "A Conversation with Sol Tax," Current Anthropology 32 (1991), 175.

51. Tax to Hoyt, $1 / 27 / 1964$, folder 4 , box 126 , STP. 
shows in the way she referred to its residents as "the Tama Indians" rather than their preferred name, Meskwaki. She did indeed misread the intent of the anthropologists in accusing them of manipulating the Meskwaki. Most importantly, Hoyt underestimated the abilities of the settlement residents by implying that they were utterly helpless in the face of the researchers' alleged attempts to impose their agenda on the Meskwaki. Hoyt would have had a better argument in that regard were it not for the way Tamacraft came about. After all, the grant application Tax wrote called for television programs and a health clinic, but the program turned into a small business in response to a Meskwaki man's suggestion.

Hoyt placed the blame for the project's failure on Tax and the other Chicago people, but members of the Meskwaki community remember it differently. Wendy Schmitz joined the cooperative and enjoyed the work, but she said the location of Tamacraft on the University of Chicago property just off the settlement gave some people the impression that it was a project for just a few families rather than the entire community. Other people did not join, Schmitz said, because they seemed to lack the entrepreneurial spirit. Furthermore, she said, lack of capital kept the enterprise from being set up efficiently. Even with the University of Chicago's $\$ 6,000$ loan, workers did much of the silk-screening and other tasks in the kitchen and living room of the university farmhouse where Rietz and his family lived. ${ }^{52}$

Others put the blame on members of the community themselves for the venture's failure. Sean Carter still refuses to speak to members of another family who participated in the project. $\mathrm{He}$ contends that some family members cheated the enterprise by intentionally spoiling many tiles they made so that they could sell them as seconds for their own profit rather than for the benefit of the cooperative. One woman who did not join the cooperative said it fell apart because the family most active in it went on to other things. Another man said the cooperative would have become a fantastic business by now had it continued. He blamed jealousy among the workers' wives for keeping some

52. Interview with the author, 6/1/2001, Meskwaki Settlement; Traer StarClipper, 1/4/1957, copy in box 9, FPP. 
people away, but suggested that the biggest problem was the one cited by Rietz-the decision to pay themselves wages rather than pay their salespeople. "It was the Indian, he wanted big money. . . . It was nobody's fault but the Indians'," he insisted. ${ }^{53}$

Whatever the cause of failure, by 1962 Tamacraft was out of business. In 1963, in response to inquiries from the University of Chicago comptroller, Tax arranged for the University of Chicago to absorb the loss of the $\$ 6,000$ loan. $^{54}$

AS WITH TAMACRAFT, the idea for the action anthropologists' other highly visible program also came not from the researchers themselves, but from a conversation between Sol Tax and the tribal chairman, Edward Davenport. Late in the summer of 1954, Davenport instigated a conversation with Tax about a college scholarship for one of his daughters. Once the seed regarding scholarships was planted in Tax's fertile mind, it blossomed into plans for a $\$ 100,000$ program to send 18 to 20 Meskwaki youth to college over a ten-year period. Tax hoped that Meskwaki youth would take up professional occupations, such as nursing and law, which they could practice in nearby communities rather than having to move to urban areas. The Meskwaki had come to believe that attending elementary and secondary school could lead to better lives for their children without threatening their Meskwaki identity, and Tax wanted the scholarship program to demonstrate that college and professional careers also were compatible with core Meskwaki values. Seeing Meskwaki in professional roles also would, he thought, increase the self-confidence of members of the community and bolster the image Tama whites held of Meskwaki. Highly educated Meskwaki might also take a larger leadership role in running settlement affairs. ${ }^{55}$

53. Interviews with the author, 6/5/2001, 7/11/2001, and 6/13/2001, Meskaki Settlement.

54. Tax to Evelyn Lord, 9/25/1957, folder: Sol Tax et al. Tama 12 (2 of 2), box 9 , FPP; Tax to Edward Boyle, 6/19/1963, folder: 6/19/1963 Memo and Following, box 16, FPP.

55. "A Program for Professional Education," folder: Fox Indians Professional Education, box 12, FPP, 82-84. 
Tax searched for money to pay for the scholarships. Finally he persuaded the Gardner Cowles Foundation, set up by the family that owned Look magazine and several other publications, including the Des Moines Register, to contribute $\$ 35,000$. The University of Iowa agreed to waive tuition and fees for the equivalent of 72 student years for all Meskwaki who chose to attend that institution, amounting to another $\$ 12,500$. Iowa State College and Iowa State Teacher's College soon followed with their own tuition waivers. Even so, Tax had trouble getting the Cowles Foundation to release its contribution because the offer stipulated that Tax first had to raise another $\$ 70,000$. Tax approached a wide range of other groups in Iowa, but he was able to come up with less than $\$ 700$ in matching funds by the fall of $1955^{56}$

Anxious to start the full program, Tax engaged in some clever accounting. He anticipated that some Meskwaki students would also qualify for scholarship aid from other sources, such as the American Missionary Association and the John Hay Whitney Foundation. By counting those expected funds, as well as whatever money students received directly from church groups or service clubs, Tax was able to show that he had $\$ 83,000$ available for scholarships. The Cowles Foundation then agreed to release its contribution. ${ }^{57}$

In the fall of 1954, Tax issued a news release about the scholarship program, which was picked up by newspapers in the area. One Meskwaki youth, Joseph Daniels, was working in Moline, Illinois, when a friend told him about a newspaper article on scholarships for Meskwaki youth. Daniels made a special trip back to the settlement on the weekend to talk to the researchers about the scholarships. He flagged down one of the students as she passed by a field where he was playing touch football. The Chicago student recorded the encounter with Daniels in these words: "He says that he wants to be a doctor and had planned to go [to college] this fall but that he did not have enough money. He seemed very excited and had a gleam in his eye. He said several times 'You don't know what this means.' ... I had been

56. Harold S. Saunders to Sol Tax, 9/14/1954, folder: Prof. Ed. Correspondence-54 on, box 10, FPP; David Kruidenier Jr. to William B. Cannon, 1/24/1955, ibid.; Tax to David Kruidenier Jr., 1/31/1956, ibid.

57. Tax to David Kruidenier Jr., 1/31/1956, ibid. 
so stunned at first that it was not till I got away that I began to get really excited. ${ }^{158}$

In 1955, three Meskwaki were able to start college with the help of the tuition breaks from the colleges and direct contributions from other sources. One attended Grinnell College, one the University of Iowa, and one Iowa State Teachers College (later the University of Northern Iowa). ${ }^{59}$ From the time it began operating in the fall of 1955 until it ran out of funds in 1962, the Fox Professional Education Scholarship Program provided college funds for 18 Meskwaki youth, in amounts ranging from $\$ 50$ to $\$ 6,423$. Among them was Daniels, who received $\$ 1,151$ for college tuition at Drake University. By 1962, the students had completed a total of 51.5 years of college, and six had graduated. Of the scholarship recipients, two became nurses, two teachers, and two went to graduate school. At least two others finished their college degrees later. Daniels was among those who did not complete his degree. After living away from the settlement, he returned in the 1990s and led the successful effort to bring casino gaming to the settlement. ${ }^{60}$

More Meskwaki youth could have been helped if the project had not ended prematurely, but Tax's tricky accounting could not make up for the underfunding of the ten-year, $\$ 100,000$ program. Compounding the problem of underfunding was several students' choice of private schools rather than taking advantage of the tuition waivers from Iowa's state universities. To overcome those difficulties, Meskwaki students and Rietz often scrambled to piece together a conglomeration of funding sources to cover a semester's expenses. Rietz doled out to students the small amount of cash from the Cowles Foundation, including a small monthly spending allowance for each student, only after scholarships had been obtained from other sources. ${ }^{61}$

58. Sarah Robinson field notes, 10/17/1954, box 288, reel 6, frame 3799, STP.

59. Robert Rietz, "Progress Report: The Fox Professional Education Program," 3/1/1957, folder: Fox/Tama Project-Memoranda, Robert Rietz Papers, Native American Education Services, Chicago.

60. Tax to David Kruidenier Jr., 5/31/1962, box 9, FPP; "A Program for Professional Education," part of MS 4802," "Action Anthropology as Field Program," box 12, STP, 84; interview with the author, 6/28/2001, Meskwaki Settlement.

61. Tax to [Meskwaki student], 10/25/1960, box 9, FPP. 
By the 1961-62 academic year, students had to write repeatedly to Tax to get their bills paid. One group of students was threatened with eviction because their room and board for the fall semester was still unpaid in December 1961. By the fall of 1962, the funds would stretch no further. When students wrote asking for funds, Tax told them that the scholarship program was broke; they should look elsewhere for funding. After promising a ten-year program, Tax had been able to deliver only seven years' worth of funding. When settlement residents learned that the scholarship fund had dried up, some immediately became suspicious. One Meskwaki who had served on the scholarship committee asked for a financial statement of the fund, including the amount of money it took in and a list of itemized expenditures and recipients. The request no doubt reflected disappointment at the early demise of the scholarship program. Still, another scholar who has written about the Meskwaki, Douglas E. Foley, correctly called the scholarship program one of the turning points in Meskwaki history because it introduced Meskwaki youth to the idea of attending college. ${ }^{62}$

The contrasting experiences of two Meskwaki demonstrate the importance of the program. When Rebecca Full Moon graduated from Tama High School in 1949, the school principal encouraged her to go to college, and she was interested in doing so. Yet when Full Moon's father asked her if she wanted to go to work or continue her education, she said she would go to work because she knew her family could not afford a college education. Tax's scholarship program was still six years in the future. Full Moon took a job as a maid/nanny for a well-off family in Cedar Rapids. Later she took business courses at Haskell Junior College, an Indian junior college in Kansas, and went on to a career as a secretary for the Bureau of Indian Affairs in South Dakota and elsewhere. ${ }^{63}$

Ruth Morris graduated from Tama High School in 1955 and was starting to think about her future when Robert Rietz came

62. [Meskwaki students] to Tax, 12/10/1961, box 17, FPP; Lee T. Gobble to "Gentlemen," 12/11/1961, ibid.; Sol Tax to [Meskwaki student], 8/2/1962, ibid.; [Meskwaki man] to Robert Rietz, 7/25/1962, box 11, FPP; Foley, Heartland Chronicles, 161-62.

63. Interview with the author, 4/24/2002, Meskwaki Settlement. 
by her house one day. "We weren't getting help from the BIA at that time [for college]. Some people went to Haskell. I wanted to go to college, but I wasn't [financially] able to go. He [Rietz] had a couple of scholarships so I was able to go with money from the Iowa Federation of Women's Club and the Kiwanis out of Waterloo," Morris said. Without Rietz's help, "I would have started looking for work probably," but because she had taken college preparatory courses, she lacked office skills, so Morris doubted that she would have had much luck. After one year at the University of Iowa, Morris transferred to a nurse training program, graduated, and spent her career in nursing away from the settlement. Morris considered the scholarship program the anthropologists' most important contribution to the community. ${ }^{64}$

Generally, men were less successful than women in completing their college educations. That strongly colored their memories of the program. One man, whose drinking and personal problems caused him to flunk out of college, could not remember that he had ever received money from the fund, even after seeing a copy of the program's report with his name in it. Some treated the experience of college life as a lark. They enjoyed living in the dormitory, partaking of campus life, and playing football without letting their academic work interfere unduly. One man was delegated by his roommates to write to Tax each month to request their spending money because he knew how to type and could write better than the others. He was surprised that his letters asking for money lingered in the project files decades later, and wished that they had been destroyed. When scholarship checks were slow to arrive, he recalled, students would charge books at the bookstore, then sell them for cash to get by. ${ }^{65}$

Some Meskwaki who did not participate in the scholarship program thought it mainly benefited individuals who took their degrees and went elsewhere. One woman asked, "What did it do for the community?" Her question reflects a preference common among settlement residents for putting service to the tribe above individual gain. Two of the scholarship recipients did

64. Interview with the author, 6/7/2002, Meskwaki Settlement.

65. Interviews with the author, 7/12/2001 and 6/26/2002, Meskwaki Settlement. 
did become tribal chairs, however, and a third helped jumpstart the effort to build a casino on settlement land. ${ }^{66}$

For other people, such as Sean Carter, the exposure to college was a life-changing experience, and the benefits of that extended beyond the Meskwaki Settlement, even if it did not immediately result in a degree. "That was the best part of their project," he recalled, "because it got me going when I didn't want to do anything, just be like everybody else." Carter had not thought about college until Rietz came by to invite him to go to Iowa City with other Meskwaki youth to see about attending the University of Iowa. Thinking they might stop for a beer afterward, Carter went along, was talked into enrolling, and came home a college freshman. Even with the tuition waiver from the university, his G.I. Bill monthly living allowance, and support from the scholarship fund, Carter still had to wash pots and pans at Joe's Place to get by financially. While requesting his monthly allowance from the program, Carter expressed his "sincerest appreciation" and asked Tax to thank Rietz personally for his assistance. ${ }^{67}$

Although he did not finish his undergraduate degree in the 1950s, Carter became tribal secretary, was instrumental in a 1968 court battle that blocked a Bureau of Indian Affairs attempt to close the settlement school, and helped found the National Coalition of Indian-Controlled School Boards, Incorporated, to help tribes run their own schools. He also helped develop Iowa's Native American Graves Protection Act to protect Indian remains, resulting in its passage in 1976, fourteen years before a similar federal statute became law. In the 1970s, Carter returned to college to finish his undergraduate degree, as well as earn two master's degrees. He considered the scholarship program to have been the catalyst for many of his activities. ${ }^{6}$

Although the program never lived up to its $\$ 100,000$ promise, the $\$ 83,000$ in aid it did provide over seven years was an enormous amount for the time. In 1955, the year the Meskwaki scholarship fund started, the Bureau of Indian Affairs had set

66. Interview with the author, 6/1/2001, Meskwaki Settlement.

67. Interview with the author, 6/5/2001, Meskwaki Settlement; [Meskwaki man] to Sol Tax, 10/31/1958, folder: Sol Tax et al., box 16, FPP.

68. Interview with the author, 6/5/2001, Meskwaki Settlement. 
aside from its budget only $\$ 10,000$ to support 54 Indian students nationwide attending college. And when in 1957 Congress established a separate fund for college education for Indians, it appropriated only $\$ 70,000$ for the nation's entire Native American population. ${ }^{69}$

IN ONE SENSE, critics like Sally Deer were correct. By hosting Chicago graduate students for a decade, the Meskwaki did help many new scholars launch their academic careers, but settlement residents were left as poor as they were before. Meskwaki did benefit, however, if the search for the program's legacy is extended beyond the settlement's physical boundaries. Sol Tax credited his experience on the settlement with his involvement in one of the watershed events in post-World War II Indian political activity, the 1961 American Indian Chicago Conference. ${ }^{70}$ That gathering of more than 450 Indians from across the country resulted in the adoption of the Declaration of Indian Purpose, which called on the federal government to abandon termination and adopt a policy that would guarantee more self-determination for tribes. As a result of his work in the Meskwaki community, Tax himself became well known in Indian policy circles and worked to try to temper federal policies towards Indians. Some of Tax's students also turned their efforts to Indian affairs. Robert K. Thomas, an Oklahoma Cherokee, for example, developed an influential theory that applied the concept of colonialism to Native Americans' status within the United States. Other Indian youth attended a workshop on Native American affairs in the 1950s that Tax established, and some went on to join the ranks of an activist national Indian leadership in the $1960 \mathrm{~s}^{71}$ To

69. Testimony of Rex Lee, director of education for Bureau of Indian Affairs, House Committee on Interior and Insular Affairs, Subcommittee on Indian Affairs, Hearings H.R. 1591, 84th Cong., 1st sess., 2/21/1955; Francis Paul Prucha, The Great Father: The United States Government and the American Indians, abridged ed. (Lincoln, NE, 1986), 353. In 2003 dollars, Tax's scholarship program provided \$515,666 in financial aid to Meskwaki students; see www.bls.gov/cpi.

70. Sol Tax, untitled, undated, handwritten document, folder 1, box 244, STP; Tax speech, 6/16/1976, folder 6, box 274, STP.

71. For a full discussion of these developments, see my dissertation, "The Meskwaki and Sol Tax: Reconsidering the Actors in Action Anthropology," (Ph.D. diss., University of Michigan, 2003). 
the extent that the Meskwaki were and are part of the broader American Indian community, these developments redounded to their benefit.

Even within the confines of the settlement, sour memories of unpaid wages or unfunded scholarships mix with sweeter remembrances - parties, friendships, and exposure to new ideas. For some, the feeling of an opportunity lost lingers. In the memory of the dwindling number of Meskwaki old enough to remember Sol Tax and the other University of Chicago anthropologists, for example, the demise of Tamacraft was due as much to Meskwaki actions as to anything the action anthropologists did. Furthermore, the project was much more than the Pushetonequa-designed tiles and silk-screened Christmas cards. Tax thought Tamacraft would give the Meskwaki experience in running a business, not the way white economists thought it should be run, but rather within the context of their own culture and values.

The scholarship program may never have produced the nucleus of Meskwaki lawyers, nurses, and doctors that Tax envisioned. It did, however, launch some people into careers. Others, after an exposure to college under the scholarship program, returned later to finish their degrees. As one man, who went on to become a leader within the tribe, said, the scholarship program was one aspect of the Chicago project that changed his life.

These memories undercut the critical evaluations of the project offered by Stucki and Hoyt, especially the claim that Tax and his associates designed a program with little regard for what Meskwaki wanted. In the case of both of the major projects, the researchers acted in direct response to a suggestion from someone in the community and did not foist anything onto unwilling people. As comments from Sally Deer and Charles Spotted Horse indicate, Meskwaki freely exercised their prerogative to accept or reject the members of the Chicago field parties, wholly or in part. Furthermore, some of the people most affected by the project either were not present when Hoyt and Stucki did their evaluations, or their accomplishments still lay in the future.

Foley's approach to the project is more comprehensive than either Hoyt's or Stucki's. In an article titled, "The Fox Project: A 
Reappraisal," Foley faults the Chicago researchers for claiming that they worked more closely with Meskwaki people than they actually did and that they tended to "initiate action projects with little prior collaboration." Foley attaches less importance to the genesis of Tamacraft than I do. He describes Tamacraft as "apparently the collective brainchild" of Pushetonequa and Rietz, without explaining why coming up with the idea fails to count as meaningful collaboration. The co-op project clearly was something Pushetonequa and other settlement residents wanted to do, based on their earlier attempts to start such a venture. Foley also contends that Rietz was Tamacraft's fundraiser and business agent, suggesting that his role displaced potential Meskwaki leaders. ${ }^{72}$ Since white bankers in Tama would not extend credit to the group, it is unclear what alternatives coop members and Rietz had other than to use funds from the Schwartzhaupt grant. ${ }^{73}$ Assessments of the Chicago project certainly would have been negative had Rietz and Tax encouraged the start of a business without figuring out some sort of seed money to get it off the ground.

Even after moving back to Chicago in 1958, Rietz, at the bank's insistence, kept his name on Tamacraft's bank account, leaving him personally on the hook for any financial problems. Although Rietz was financially responsible for the project, he was not handling the group's money in 1962. He wrote to Tax that "they do this themselves. They have been banking their money and paying their bills directly, without keeping me informed." Rietz did not interfere with this arrangement, saying he kept "such records as the Fox [Meskwaki] want me to keep." Surely that arrangement is some form of collaboration. ${ }^{74}$

In the case of the scholarship program, Foley attaches no importance to Davenport's conversation with Tax about a scholarship for his daughter. Davenport deserves some of the credit for planting the seed, however, since Tax had never mentioned the scholarship program in any writings prior to that conversation. Tax did raise the money, obviously, since if Dav-

72. Foley, "Fox Project" (quotation on p. 177).

73. Rietz to Tax, 10/14/1962, folder 4, box 126, STP.

74. Ibid. 
enport had known where to get money for scholarships he probably would not have bothered to ask Tax. ${ }^{75}$

Much of Foley's critique of the project deals with matters pertaining more to academic issues than to settlement residents. For example, he enters the dispute within the field of anthropology over how much Tax and his associates differed from the rest of their colleagues in the 1950s. His conclusion is that the project, while fascinating, "may not have been as innovative as Tax and some of his more ardent defenders claim" and that in many ways their theoretical ideas were typical of the 1950s rather than a radical departure from them. ${ }^{76}$ As a historian, my concern is less with the project's effects on the field of anthropology than on Indians themselves, both on the settlement and nationally. My aim is to present what Linda Tuhiwai Smith describes as a "counter-story" of the project; that is, the history of the research from the eyes of the subjects of the research. ${ }^{77}$ Meskwaki perspectives provide an alternative not only to what the Chicago anthropologists wrote about the project, but also to what the project's subsequent academic reviewers wrote about it.

Foley combines the comments he collected into a single, community-wide judgment, finding the Chicago students and their projects amusing and well intentioned, but naïve. ${ }^{78}$ Such an approach tends to flatten out differences in individual opinions on the project. Having de-emphasized the academic debate in my work, I uncovered a range of individual reactions. I did find amusement, but I also found more resentment (Sally Deer) and more significant personal change (Cathy Arrow) than Foley presented. My approach involves less filtering of Meskwaki opinions and allows individual voices to be heard without requiring that they represent the entire group.

75. Foley is incorrect when he states (in Heartland Chronicles, 161-62) that Tax got $\$ 100,000$ for scholarships from a New York foundation. The Gardner Cowles Foundation, based in Des Moines, was the source, and it contributed only $\$ 35,000$.

76. Foley, "Fox Project," 183.

77. Linda Tuhiwai Smith, Decolonizing Methodologies: Research and Indigenous Peoples (London and New York, 1999), 3.

78. Foley, "Fox Project," 179. 
This Meskwaki counter-story of action anthropology means that, despite the absence of a continuing Tamacraft factory turning out items of Meskwaki-crafted artwork, the legacy of action anthropology within the settlement should not be reduced to the occasional ceramic tile that shows up at a local garage sale. Determining the legacy of action anthropology requires taking a view that is both comprehensive and fragmented to allow for long-term consequences and individual differences in experiences and outcomes. Determining the legacy also requires less privileging of academic viewpoints of the project based on its influence within anthropology and more in-depth focus on Meskwaki evaluations of the project. 
Copyright of Annals of Iowa is the property of State of Iowa, by \& through the State Historical Society of Iowa and its content may not be copied or emailed to multiple sites or posted to a listserv without the copyright holder's express written permission. However, users may print, download, or email articles for individual use. 